\title{
Penggunaan Smartphone pada Konstruksi Belajar Siswa MTs Negeri 7 Model Jakarta
}

\author{
Najwaa Chadeeja Alhady ${ }^{1)}$; Ara Fahana Salsabila' ${ }^{2}$; Nazula Nur Azizah ${ }^{3)}$ \\ Madrasah Tsanawiyah Negeri 7 Jakarta
}

Corresponding Author: alhadynajwa@gmail.com

\begin{abstract}
This paper attempts to determine the characteristics of students in using the internet/smartphone and how the internet/smartphone influence the cognitive, social and emotional development of students. This quantitative research reveals the characteristics of internet usage among teenagers, especially regarding the duration of time to access internet/smartphone, the amount of data usage and source of financing the purchase of data/balance. The results revealed the effect of internet/smartphone on student achievement. Achievements in social, skills and communication subjects have greater scores compared to specific subjects (Mathematics and Science). This explains that students who use the Internet have broader insights, foreign language skills, and are able to develop their creativity. The best time to use is in the range of 7 until 11 hours per week or 1 until 1,5 hours per day. While the use under 7 hours per week and use of over 11 hours per week do not have a significant effect on cognitive improvement.
\end{abstract}

Keywords: cognitive; effect of the internet; emotional; social; youth

\begin{abstract}
Abstrak
Penelitian ini berupaya mengetahui karakteristik siswa dalam menggunakan internet/smartphone dan bagaimana pengaruh penggunaan tersebutterhadap perkembangan kognitif, sosial dan emosi siswa. Hasil penelitian menunjukan adanya pengaruh penggunaan internet/smartphone terhadap prestasi siswa. Pengaruh tersebut tidak selalu berdampak negatif terhadap capaian prestasi. Capaian prestasi pada mata pelajaran sosial, keterampilan dan komunikasi memiliki skor yang lebih besar dibandingkan dengan pelajaran eksakta (Matematika dan IPA). Siswa yang menggunakan internet memiliki wawasan yang lebih luas, memiliki keterampilan berbahasa asing, dan mampu mengembangkan kreatifitasnya. Rentang penggunaan waktu terbaik (ideal) berada pada kisaran 7-11 jam per minggu atau 1-1, 5 jam per hari. Sedangkan penggunaan di bawah 7 jam per minggu dan penggunaan di atas 11 jam per minggu tidak memberikan pengaruh yang berarti terhadap peningkatan kognitif.
\end{abstract}

Kata kunci:emosi; pengaruh internet; remaja; sosial

\section{A. Pendahuluan}

Perkembangan teknologi informasi dan komunikasi sudah sedemikian cepat sehingga tanpa disadari sudah mempengaruhi setiap aspek kehidupan manusia. Dewasa ini produk teknologi sudah menjadi kebutuhan sehari-hari dalam menjalankan aktivitas kehidupan. Penggunaan internet sudah bukan menjadi hal yang aneh ataupun baru lagi, khususnya di kotakota besar bahkan sudah menjadi media paling penting dalam media pemasaran. ${ }^{1}$ Bahkan kemajuan teknologi seperti televisi, smartphone, laptop, bahkan internet bukan hanya melanda masyarakat yang hidup di perkotaan namun dapat dinikmati oleh masyarakat di pelosokpelosok desa.

Penggunaan internet khususnya smartphone di Indonesia terus meningkat dari tahun ke tahun. Indonesia menjadi negara dengan pengguna aktif smartphone terbesar di dunia setelah

${ }^{1}$ Dewi Irmawati, "Pemanfaatan E-Commerce Dalam Dunia Bisnis", Jurnal Ilmiah Orasi Bisnis, Edisi Ke-VI, (November 2011): 95-112. 
China, India, dan Amerika ${ }^{2}$. Bahkan, hasil riset menunjukan Indonesia berada diperingkat ketiga dalam daftar pengguna smartphone terbesar di asia pasifik dengan jumlah pengguna 83,18 juta pada tahun $2018^{3}$. Pengguna tersebut terdiri dari berbagai kalangan termasuk kalangan peserta didik yang masih duduk di bangku SMP. Menurut pewinternet.com, pengguna internet didominasi oleh kalangan remaja usia 12-18 tahun dengan presentase 93\%. ${ }^{4}$ Telepon pintar atau smartphone menjadi kebutuhan yang sangat penting bagi kehidupan saat ini yang memerlukan mobilitas tinggi. Fasilitas-fasilitas yang terdapat didalamnya pun tidak hanya terbatas pada fungsi telepon dan SMS (short messages service) saja. Smartphone dapat digunakan sebagai sarana pembelajaran, artinya dengan smartphone seseorang dapat mempelajari hal-hal baru melalui isi atau pesan yang disalurkan ${ }^{5}$. Telepon pintar atau yang biasa disebut smartphone dapat digunakan sebagai sarana bisnis, penyimpan berbagai macam data, sarana musik/hiburan, bahkan sebagai alat dokumentasi. Hal ini menjadikan smartphone sebagai salah satu perkembangan komunikasi yang paling aktual di Indonesia selama lebih dari lima tahun terakhir.

Hampir setiap individu mulai dari anak-anak hingga orang tua kini memiliki smartphone. Tentu saja hal ini bukan hanya terjadi tanpa alasan karena daya konsumsi dan kebutuhan masyarakat saat ini sudah sangat jauh berbeda dibandingkan beberapa dekade ke belakang. Kini kebutuhan akan komunikasi dan informasi menjadi hal yang paling penting bagi semua kalangan masyarakat, ditambah dengan mudahnya mengakses berbagai macam layanan (fitur) yang ditawarkan dari penyedia jasa layanan dari produsen smartphone itu sendiri dan berbagai provider pendukung. Smartphone memiliki fitur menarik yang ditawarkan dan seringkali membuat anak-anak cepat akrab dengannya. Dengan berbagai macam fitur menarik, gadget ini diperuntukan bagi remaja dan juga dewasa dengan aplikasi khusus bagi mereka. ${ }^{6}$

Sebanyak 36 persen pengguna smartphone Indonesia menghabiskan waktu 4-8 jam dalam sehari memakai perangkat bergeraknya. Sebuah survei yang dilakukan CLSA pada 2015 menunjukkan lebih dari 90\% pengguna smartphone memerlukan waktu tidak kurang dari 2 jam per hari dalam menggunakan perangkat ponsel pintar. Bahkan, 32,5 persen pengguna smartphone ini membutuhkan lebih dari 8 jam untuk mengakses ponselnya. ${ }^{7}$

Penggunaan internet termasuk smartphone juga memiliki manfaat positif jika dapat digunakan dengan baik untuk mempermudah komunikasi dan mengkases informasi, termasuk dalam media pembelajaran. Smartphone merupakan salah satu alat yang memiliki teknologi yang canggih. Jadi semua orang dapat dengan mudah berkomunikasi. Membangun kreatifitas anak (smartphone memberikan beragam informasi yang juga bisa mendorong anak menjadi

\footnotetext{
${ }^{2}$ Feby Novalius, "Indonesia Pengguna Smartphone Ke-4 Dunia, Begini Tekad Menperin Dongkrak Industri Telematika”, https://economy.okezone.com/read/2018/02/17/320/1860752/indonesia-penggunasmartphone-ke-4-dunia-begini-tekad-menperin-dongkrak-industri-telematika, diakses 2 Oktober 2018.

3 Data dari katadata.co.id, "Pengguna Smartphone Tertinggi di Asia-Pasifik 2016- Databoks", https://databoks.katadata.co.id/datapublish/2016/08/08/pengguna-smartphone-tertinggi-di-asia-pasifik-2016, diakses 11 Januari 2018

${ }^{4}$ PewResearchCenter, "Internet User by Age Groups". http://www.pewinternet.org/, diakses 2 januari 2017.

${ }^{5}$ Intan Trivena Maria Daeng N.N Mewengkang Edmon R Kalesaran, "Penggunaan Smartphone Dalam Menunjang Aktivitas Perkuliahan Oleh Mahasiswa Fispol Unsrat Manado”, e-journal Acta Diurna, Vol. VI. No. 1. Tahun 2017: 1-15.

${ }^{6}$ Nadhila Isna, "Mempermudah Hidup Manusia dengan Teknologi Modern”,

(Online).(http://komunikasi.us/index.php/mata-kuliah/kmm/12-response-paper-ptk-2013/375mempermudahhidup-manusia-dengan-teknologi-modern), Diakses 12 April 2017.

7 Katadata.co.id, “33\% Pengguna Akses Ponsel Pintar lebih dari 8 Jam/Hari - Databoks,", https://databoks.katadata.co.id/datapublish/2016/11/02/33-pengguna-smartphone-akses-perangkatnya-lebih-dari8-jam-per-hari, diakses 11 Januari 2018
} 
lebih kreatif). Dengan menggunakan smartphone, anak akan lebih mudah mencari segala informasi dan berita yang dibutuhkan olehnya, terutama dalam hal belajar sambil bermain ataupun bermain sambil belajar. Dalam usia ini, anak memang masih berada di dalam masa yang mengasyikan untuk bermain. Namun tak melepaskan diri dari sebuah proses pembelajaran yang juga harus dilakukan.

Namun demikian, penggunaan smartphone secara berlanjut akan berdampak buruk bagi pola perilaku anak dalam kesehariannya, anak-anak yang cenderung terus-menerus menggunakan smartphone akan sangat tergantung dan menjadi kegiatan yang harus dan rutin dilakukan oleh anak dalam aktifitas sehari-hari. Penggunaan gadget yang terlalau lama nyatanya dapat berpengaruh pada konsentrasi anak, dimana selama jam pelajaran berlangsung dapat dilihat dari tingkat prestasi anak di sekolah ${ }^{8}$. Tidak dipungkiri saat ini anak lebih sering bermain smartphone dari pada belajar dan berinteraksi dengan lingkungan sekitarnya, Hal ini mengkhawatirkan, sebab pada masa anak-anak mereka masih tidak stabil, memiliki rasa keingin tahuan yang sangat tinggi, dan berpengaruh pada meningkatnya sifat konsumtif pada anak-anak untuk itu penggunaan smartphone pada anak-anak perlu mendapatkan perhatian khusus bagi orang tua. Beberapa kasus mengenai dampak negatif dari smartphone ini sering sekali menimpa anak-anak. Mulai dari kecanduan internet, game, dan juga konten-konten yang berisi pornografi. ${ }^{9}$ Berdasarkan uraian diatas, nampak bahwa di samping memberikan manfaat positif internet/smartphone dapat memberikan pengaruh yang buruk.

Merespon keberadaan internet yang semakin mewabah dikalangan masyarakat, termasuk generasi muda, Depdiknas telah mengembangkan pembelajaran melalui internet dengan membangun backbone Jejaring Pendidikan Nasional, atau populer dengan istilah Jardiknas. ${ }^{10}$ Menindaklanjuti hal tersebut, perlu dilakukannya berbagai upaya untuk merancang materi pembelajaran yang dapat meningkatkan ketertarikan siswa sehingga dapat meningkatkan prestasi mereka dalam mata pelajaran.

Berbagai hasil penelitian menunjukan bahwa penggunaan internet khususnya smartphone dapat memberikan manfaat positif dan negatif bagi keberhasilan belajar siswa. Sebagaimana yang dilakukan Beauty Manumpil Yudi Ismanto Franly Onibala tentang Penggunaan Gadget Dengan Tingkat Prestasi Siswa Di SMA Negeri 9 Manado yang menemukan bahwa siswa SMA Negeri 9 Manado jarang menggunakan gadget dan mereka nyatanya memiliki tingkat prestasi yang tinggi. ${ }^{11}$ Penelitian lain dilakukan oleh Astrid Kurnia Sherlyanita \& Nur Aini Rakhmawati tentang pengaruh dan pola aktivitas penggunaan internet serta media sosial Siswa SMPN 52 Surabaya yang menemukan bahwa siswa SMPN 52 Surabaya secara umum sudah dapat menentukan penggunaan internet secara baik, baik untuk sarana pembelajaran maupun fungsi hiburan secara seimbang dan sesuai dengan porsinya. ${ }^{12}$ Dengan asumsi penggunaan internet secara positif, maka studi eksperimen dilakukan oleh Muhammad Win Afgani, Darmawijoyo, dan Purwoko tentang Pengembangan Media Website Pembelajaran Materi Program Linear Untuk Siswa Sekolah Menengah Atas Negeri 1 Palembang dalam mata pelajaran Matematika. Penelitian ini menemukan bahwa prototype media website yang dirancang merupakan disain yang efektif ketika digunakan pada saat pembelajaran, dimana

\footnotetext{
${ }^{8}$ Beauty Manumpil, Yudi Ismanto, Franly Onibala, "Hubungan Penggunaan Gadget Dengan Tingkat Prestasi Siswa Di SMA Negeri 9 Manado”, ejoural Keperawatan (e-Kep), Vol. 3. No. 2 (April 2015).

${ }^{5}$ M. Hafiz Al-Ayouby, "Dampak Penggunaan Gadget Pada Anak Usia Dini (Studi di PAUD dan TK.Handayani Bandar Lampung)”. Skripsi Universitas Lampung 2017

10 Saragih, H P, "Belajar Tak Lagi Membosankan". www.wartaekonomi.com. (http://detiknas.in/donesia/2007/09/19/belajartak-lagi-membosankan/, diakses tanggal 27 Oktober 2017.

${ }^{11}$ Beauty Manumpil, Yudi Ismanto, Franly Onibala...

${ }^{12}$ Astrid Kurnia Sherlyanita \& Nur Aini Rakhmawati, "Pengaruh dan Pola Aktivitas Penggunaan Internet serta Media Sosial pada Siswa SMPN 52 Surabaya”, Journal of Information Systems Engineering and Business Intelligence, Vol. 2, No. 1 (April 2016): 17-22.
} 
71,79\% siswa Termotivasi; 61,54\% siswa mempunyai sikap Tertarik, dan hasil belajar siswa yang mencapai $51,28 \%$ dengan kategori sangat baik. Dengan demikian maka website yang dikembangkan sangat efektif digunakan pada saat pembelajaran matematika. ${ }^{13}$ Hasil penelitian Tania Clara Dewanti, Widada, dan Triyono ${ }^{14}$ pada SMA Negeri 9 Malang menemukan bahwa para siswa mendapatkan manfaat sangat banyak dari internet sebagai media belajar. Hasil yang berbeda ditemukan Rahardiyan ${ }^{15}$ yang menunjukan bahwa para siswa yang mendapatkan manfaat internet sebagai media belajar yaitu mendapatkan manfaat dengan taraf tinggi sebanyak 40 orang $(43,96 \%)$, sedang sebanyak 32 orang $(35,16 \%)$ dan rendah sebanyak 19 orang $(20,88 \%)$. Namun dalam penelitian ini Rahardian tidak mengungkap berapa lama waktu terbaik penggunaan internet/smartphonen yang memberikan pengaruh positif dan berapa lama intensitas internet yang memberikan pengaruh negatif. Berbeda dengan penelitian-penelitian sebelumnya, penelitian ini menitikberatkan pada pengujian rekonstruksi kognitif, sosial, dan emosional siswa melalui penggunaan internet pada satu SMK di Jakarta, yaitu siswa MTs Negeri 7 Model Jakarta. Lebih khusus, penelitian ini akan melihat pengaruh penggunaan internet/smartphone terhadap kognitif, sosial, emosional pelajar, serta seberapa besar pengaruh penggunaan internet/smartphone terhadap kognitif, sosial, emosional siswa.

Penelitian ini dilaksanakan di Madrasah Tsanawiyyah Negeri 7 Jakarta dengan menetapkan 60 siswa sebagai sample dengan cara metode random sampling dimana agar tercapai keterwakilan setiap kelas, maka dipilih 20 siswa pada masing-masing kelas, sementara pada setiap kelas kuesioner disebarkan secara acak pada tiap-tiap ruang kelas. Dilihat dari struktur umur responden adalah remaja yang berumur antara 12-15 tahun. Seluruhnya berasal dari kelas VII sampai kelas XI pada MTs Negeri 7 Model Jakarta. Populasi penelitian ini sebanyak 600 siswa yang tersebar pada 18 kelas, yaitu kelas VII sebanyak 6 kelas berjumlah 240 siswa, kelas VIII ada 6 kelas berjumlah 240 siswa, dan kelas IX ada 6 kelas berjumlah 240 siswa. Penelitian dilakukan selama tiga bulan yakni bulan Nopember 2017-Januari 2018 dengan menetapkan dua variabel, yaitu variabel $\mathrm{X}$ sebagai variable bebas, berupa penggunaan alat komunikasi smartphone; dan variabel Y yaitu prestasi siswa yang merupakan variabel terikat. Untuk menguatkan data dilakukan pula teknik waancara dan observasi dan a

\section{B. Penggunaan Internet dan Smartphone dan Pandangan Siswa}

Teknologi internet memberikan memudahkan siswa sebagai sumber dan media belajar. Pemanfaatan internet sebagai sumber dan media belajar mampu membantu siswa agar dapat belajar mandiri. Siswa dapat mengakses secara daring (online) berbagai macam jenis informasi seperti perpustakaan, jurnal, biografi, rekaman, koran, sejarah dan yang lainnya. Dalam hal ini menurut Yudi siswa dapat berperan sebagai seorang peneliti, analisis atau apa saja dan tidak hanya konsumen informasi saja. ${ }^{16}$

Informasi yang dianalisis dapat berupa informasi yang relevan dengan materi yang sedang dipelajari. Melalui internet, siswa juga dapat saling bekerja sama dengan siswa lain dengan saling mengirim e-mail untuk mendiskusikan bahan ajar atau sekedar bertukar pendapat. Internet memiliki efek yang baik terhadap proses dan hasil belajar siswa di kelas maupun di luar kelas seperti di ruang praktik. Terjadinya kemandirian, akselerasi, pengayaan

\footnotetext{
${ }^{13}$ Muhammad Win Afgani, Darmawijoyo, dan Purwoko, "Pengembangan Media Website Pembelajaran Materi Program Linear Untuk Siswa Sekolah Menengah Atas”, Jurnal Pendidikan Matematika, Vol. 2. No.2, (Juli-Des 2008): 45-59.

14 Tania Clara Dewanti, Widada \& Triyono, "Hubungan Keterampilan Sosial Dan Penggunaan Gadget Smartphone Dengan Prestasi Belajar Siswa Sma Negeri 9 Malang”, Jurnal Kajian Bimbingan dan Konseling Vol 1, No. 3, 2016: 126-131

${ }^{15}$ Elfan Rahardiyan K., Pemanfaatan Internet Dan Dampaknya Pada Pelajar Sekolah Menengah Atas Di Surabaya, dalam http://journal.unair.ac.id/filerPDF/ln5ba2011865full.pdf (diakses 15 Pebruari 2018)

${ }^{16}$ Yudhi Munadi, Media Pembelajaran: Sebuah Pendekatan Baru. Jakarta, 2013, h. 155
} 
perluasan, efektivitas dan produktivitas pembelajaran dapat terjadi dalam penggunaan internet bagi siswa. Dalam pembelajaran Korespondensi, pemanfaatan Internet dapat dilihat dari pencarian materi-materi, membandingkan materi surat yang ada di buku dan yang ada di internet, serta contoh-contoh bentuk surat yang ada di Internet.

Menurut Susena, internet memberikan dampak Positif sekaligus dampak negatif. Dampak positif seperti kemudahan dalam memperoleh informasi, internet mendukung transaksi dan operasi bisnis atau yang dikenal dengan sebutan e-business, internet bermanfaat sebagai media belajar, hiburan, dan komunikasi. Sedangkan dampak negatifnya internet menyebabkan berkurangnya sifat sosial pada siswa, pola interaksi siswa berkurang dan menyebabkan siswa mengetahui tindakan kejahatan. ${ }^{17}$

Sementara itu penggunaan perangkat (gadget) smartphone secara menerus akan berdampak buruk bagi pola perilaku anak dalam kesehariannya, anak-anak yang cenderung terus-menerus menggunakan gadget akan sangat tergantung dan menjadi kegiatan yang harus dan rutin dilakukan oleh anak dalam aktifitas sehari-hari, tidak dipungkiri saat ini anak lebih sering bermain gadget dari pada belajar dan berinteraksi dengan lingkungan sekitarnya, Hal ini mengkhawatirkan, sebab pada masa anak-anak mereka masih tidak stabil, memiliki rasa keingintahuan yang sangat tinggi, dan berpengaruh pada meningkatnya sifat konsumtif pada anak-anakuntuk itu penggunaan gadget pada anak-anak perlu mendapatkan perhatian khusus bagi orang tua. Dampak negatif gadget terkait erat dengan risiko cybercrime. Laporan Norton Online Family Report sebagaimana dilansir Liputan6.com menlaporkan bahwa di beberapa kota di Indonesia, anak-anak usia 10-17 tahun 55\% anak telah menyaksikan gambar kekerasan dan pornografi, 35\% mengaku dihubungi orang yang tidak dikenal, dan $28 \%$ pernah mengalami penipuan $^{18}$. Data ini belum termasuk kasus-kasus penculikan atau perdagangan anak, bullying, dan pornografi pada anak yang semunya disebabkan oleh penggunaan gadget pada anak-anak. Anak dengan demikian sangat rentan bahkan sampai kecanduan internet, game, dan juga konten-konten yang berisi pornografi. Dalam banyak kasus anak-anak jaman sekarangcenderung lebih mementingkan smartphone-nya sendiri dan lebih asik dengan gadgetnya daripada berkomunikasi atau mendengarkan perintah dari orangtua.

Dari aspek kesehatan, sejumlah penelitian mengungkapkan dampak buruk smartphone bagi penggunanya, baik aspek fisik maupun psikis. ${ }^{19}$ Terutama anak anak yang sedang mengalami masa pertumbuhan mereka. Beberapa pengaruh smartphone bagi kesehatan adalah susah tidur, kurang gerak, Gangguan pada mata, nyeri / Sakit, Konsentrasi jadi pendek, Kemampuan bersosialisasi berkurang, Rasa cemas yang berlebihan, Gangguan mental, Perilaku agresif, pelupa, kecanduan, terkena radiasi. ${ }^{20}$ Dari beberapa dampak negatif dari intensitas pemanfaatan internet, dampak negatif yang dominan mempengaruhi siswa adalah internet bisa menurunkan pola interaksi siswa dalam lingkungan sosialnya, sikap anti sosial, perkenalan kepada dunia kejahatan, maupun kecanduan terhadap hal-hal negatif tidak sempat dialami oleh para siswa yang intensitas pemanfaatan internetnya tergolong berat sekalipun.

17 Edy Susena, "Dampak Penggunaan Internet Terhadap Kecerdasan Pelajar", 2016, dalam http://www.poltekindonusa.ac.id/wp-content/uploads/2016/05/Vol-1-2-2014-DAMPAK-PENGGUNAAN INTERNET-TERHADAP-KECERDASAN-PELAJAR-Edy-Susena.pdf; Lihat pula Blais, “Adolescents Online: The Importance of Internet Activity Choice to Salient Relationships", Journal Youth Adolescence, 37:522536. (Online). (http://repository.unand.ac.id), Diakses 12 April 2017.

18 Liputan6, “Anak Asuhan Gadget”, https://www.liputan6.com/health/read/2460330/anak-asuhangadget, diakses 12 Oktober 2018.

19 Liputan6, https://www.liputan6.com/tekno/read/3593233/wajib-tahu-ini-dampak-buruk-smartphoneke-tubuh-dan-otak, diakses 3 Maret 2018

20 "14 Dampak Buruk Smartphone Bagi Anak Tercinta - Jurnal Web" diakses 11 Januari 2018, https://www.jurnalweb.com/dampak-buruk-smartphone-bagi-anak/ 
Bagi kalangan siswa Madrasah Tsanawiyyah Negeri 7 Jakarta, kehadiran internet juga sangat familiar bagi siswa di sekolah ini. Hal ini dinyatakan oleh 43 responden (72\%) yang menyatakan bahwa internet sangat penting. Namun sebagian lagi menyatakan bahwa internet tidak terlalu penting (27\%) sedangkan yang menyatakan tidak penting sebanyak $1 \%$ sebagaimana pada gambar berikut.

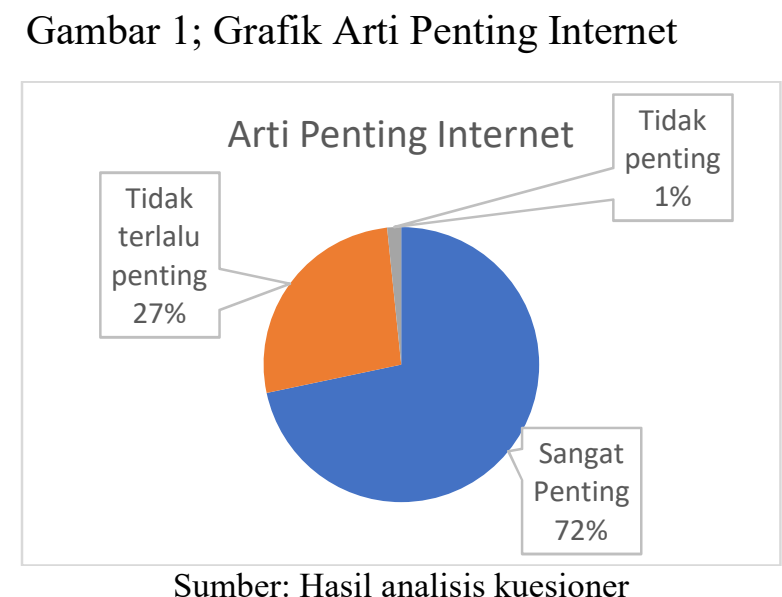

Sebagian besar remaja mengakses internet melalui perangkat cerdas (smartphone). Hal tersebut diketahui dari hasil suvei dimana 92\% responden menggunakan smartphone, sementara yang menggunakan warung internet (Warnet) sebanyak 2\%, dan sisanya 7\% responden menggunakan perangkat smartphone dan Warnet. Akses terhadap internet bagi seluruh responden hanya dilakukan di luar lingkungan sekolah. Hal ini berdasarkan kebijakan dan aturan sekolah yang melarang penggunaan internet pada saat siswa bersekolah. Akses internet yang dilakukan di luar sekolah atau rumah masing-masing siswa menggunakan akses data dari provider kartu berbayar pada smartphone dan sambungan WIFI.

Banyaknya konsumsi data yang dihabiskan oleh masing-masing responden sebagian besar di atas 1 Gigabyte (GB) per bulan, yakni dinyatakan $80 \%$ responden, sedangkan $17 \%$ menggunakan 500 Megabyte (MB) hingga $1 \mathrm{~GB}$ per bulan, dan hanya 3\% responden yang mengaku hanya menghabiskan kurangd ari $500 \mathrm{MB}$ per bulan. Belanja pulsa untuk aktivasi paket data berkisar antara 25.000-50.000 Rupiah yang dinyatakan oleh 70\% responden, sisanya $17 \%$ mengaku membeli pulsa kurang dari 25.000 Rupiah dan $13 \%$ responden membeli pulsa di atas 50.000 Rupiah. Sumber pembelian pulsa dan data cukup beragam, sebagian besar sudah mampu menyisihkan uang jajan untuk pembelian pulsa (dilakukan oleh 33\% responden). Meskipun demikian 32\% responden mengaku masih membebankan biaya pembelian pulsa kepada orang tua, dan $20 \%$ dari sumber lainnya.

Informasi mengenai akses penggunaan internet dapat dilihat pada grafik dalam gambar di bawah ini. 
Gambar 2; Belanja Pulsa/Data dan Sumber Pembiayaan

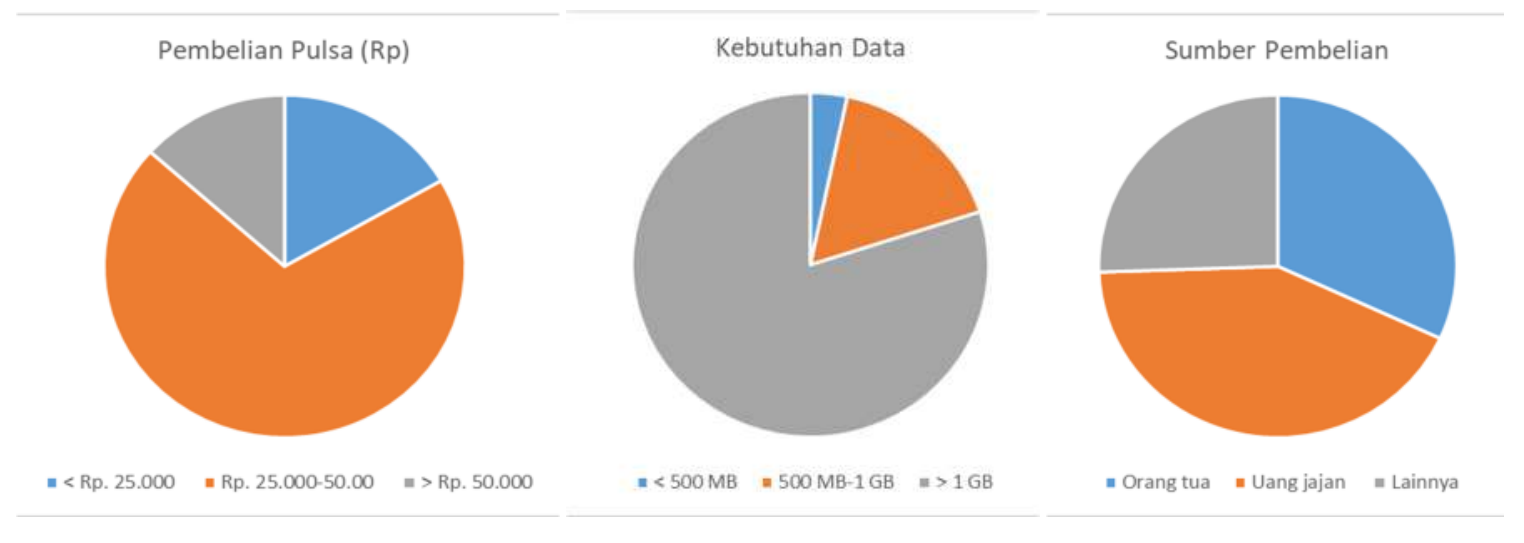

Sumber: Hasil analisis kuesioner

Siswa yang menjadi responden dalam penelitian ini mengaku menggunakan internet setiap hari, yakni dinyatakan oleh $80 \%$ responden, $13 \%$ responden hanya mengakses internet pada hari libur sekolah (hari sabtu dan minggu saja), sedangkan 7\% menggunakan internet 3-5 hari dalam seminggu. Lebih lengkapnya tersaji pada gambar di bawah ini.

\section{Gambar 3 Intensitas Penggunaan Internet/Smartphone}

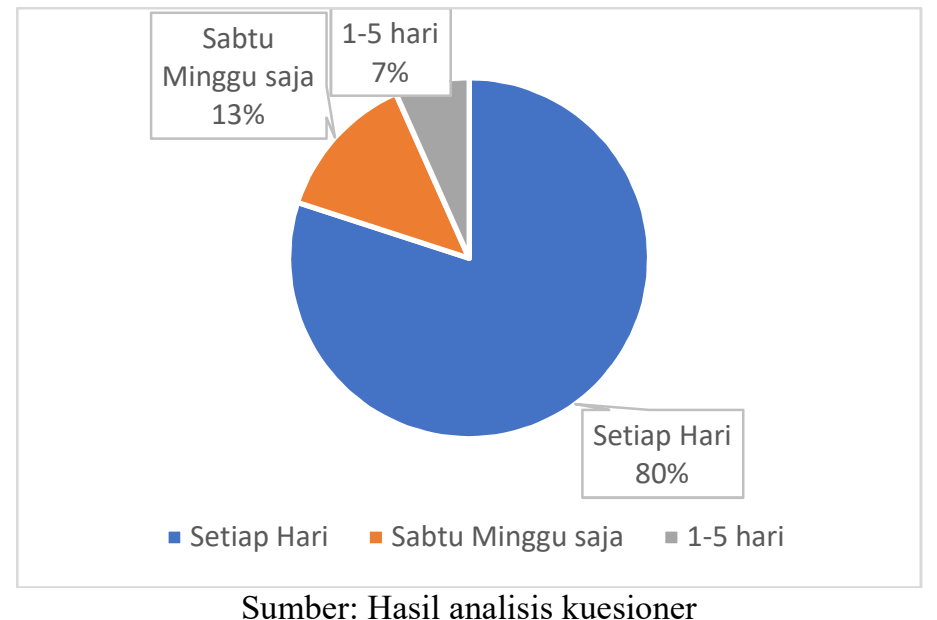

Dilihat dari lamanya penggunaan, 39,33\% responden menghabiskan waktu antara 1-5 jam per hari untuk mengakses internet, 34\% menghabiskan waktu kurang dari 1 jam, dan $26,67 \%$ menghabiskan waktu lebih dari 5 jam. Lebih jelasnya lihat tabel di bawah ini. 
Tabel 1; Durasi Waktu Penggunaan Internet

\begin{tabular}{|c|c|c|c|c|c|c|c|c|}
\hline \multirow[b]{2}{*}{ No. } & \multirow[b]{2}{*}{$\begin{array}{l}\text { Kelompok } \\
\text { Pengunaan }\end{array}$} & \multicolumn{7}{|c|}{ JUMLAH PENGGUNA (Orang) } \\
\hline & & $\begin{array}{l}\text { Video/ } \\
\text { Musik }\end{array}$ & $\begin{array}{c}\text { Media } \\
\text { Sosial }\end{array}$ & Game & Belajar & $\begin{array}{c}\text { Diluar } \\
\text { sekolah }\end{array}$ & Jumlah & Persentase \\
\hline 1 & Kurang dari 1 jam & 20 & 12 & 38 & 10 & 22 & 102 & 34.00 \\
\hline 2 & $1-5 \mathrm{jam}$ & 24 & 24 & 12 & 42 & 16 & 118 & 39.33 \\
\hline 3 & $>5 \mathrm{jam}$ & 16 & 24 & 10 & 8 & 22 & 80 & 26.67 \\
\hline & Total & 60 & 60 & 60 & 60 & 60 & 300 & 100 \\
\hline & Persentase & 20.00 & 20.00 & 20.00 & 20.00 & 20.00 & 100 & \\
\hline
\end{tabular}

Sumber: Hasil analisis kuesioner

Siswa yang hampir setiap hari akan menggunakan gadget yang mereka miliki, baik untuk kepentingan mengakses pelajaran dan pengatahuan tambahan maupun komunikasi dengan orang lain. Maka, dapat dipahami jika kekerapan atau frekwensi keseringan siswa dalam menggunakan gadget ikut mempengaruhi proses belajar mengajar mereka.

Dilihat dari kontennya, sebagian bersar alokasi waktu dihabiskan untuk media sosial (social media) yakni 24,93\%, 21,58\% untuk melakukan browsing di luar keperluan sekolah, $20,11 \%$ dihabiskan untuk menonton video dan musik dan 20,11\% untuk browsing keperluan sekolah (belajar) dan sisianya 13,27\% dihabiskan untuk bermain game baik online maupun offline. Lebih lengkapnya disajikan pada tabel di bawah ini.

Tabel 2; Waktu Penggunaan Menurut Konten

\begin{tabular}{lcccccccc}
\hline \multirow{2}{*}{ No. } & $\begin{array}{c}\text { Kelompok } \\
\text { Penggunaan }\end{array}$ & $\begin{array}{c}\text { Video/ } \\
\text { Musik }\end{array}$ & $\begin{array}{c}\text { Media } \\
\text { Sosial }\end{array}$ & Game & Belajar & $\begin{array}{c}\text { Diluar } \\
\text { sekolah }\end{array}$ & Jumlah & \% \\
\hline 1 & $<1$ jam & 10 & 6 & 19 & 5 & 11 & 51 & 6.84 \\
2 & $1-5$ jam & 60 & 60 & 30 & 105 & 40 & 295 & 39.54 \\
3 & $>5$ jam & 80 & 120 & 50 & 40 & 110 & 400 & 53.62 \\
\hline Total & 150 & 186 & 99 & 150 & 161 & 746 & 100 \\
\hline Persentase & 20.11 & 24.93 & 13.27 & 20.11 & 21.58 & 100 & \\
\hline Rata-rata penggunaan \\
(siswa/jam/hari
\end{tabular}

Sumber: Hasil analisis kuesioner

Seringnya siswa menggunakan smartphone dengan berbagai macam keperluan sebagaimana data diatas, perlu penanganan bijak, baik dari orang tua maupun sekolah. Sekolah dalam hal ini perlu menetapkan seperangkat aturan atau tata tertib, misalnya pembatasan dan larangan penggunaan smartphone selama jam-jam sekolah agar siswa lebih fokus pada mata pelajaran. Keterlibatan guru juga sangat diperlukan dalam memberikan informasi serta penekanan terhadap dampak buruk dari smartphone jika digunakan terlalu lama dan sering.

Apabila durasi penggunaan dijumlahkan dan kemudian di-sortir secara sederhana dengan mengurutkan berdasarkan durasinya dari tinggi ke durasi rendah, maka diperoleh hasil sebagai berikut: 
Tabel 3; Hasil Sortir Responden Menurut Durasi Penggunaan Internet

\begin{tabular}{|c|c|c|c|c|c|c|c|c|c|}
\hline $\begin{array}{c}\text { Durasi } \\
\text { (Jam/ } \\
\text { Minggu) }\end{array}$ & $\begin{array}{l}\text { Nilai } \\
\text { MTK }\end{array}$ & $\begin{array}{l}\text { Nilai } \\
\text { IPA }\end{array}$ & $\begin{array}{c}\text { Nilai } \\
\text { B.Ind }\end{array}$ & $\begin{array}{c}\text { Nilai B. } \\
\text { Ingg }\end{array}$ & Nilai SB & $\begin{array}{c}\text { Nilai } \\
\text { PraKar }\end{array}$ & $\begin{array}{c}\text { Nilai } \\
\text { IPS }\end{array}$ & $\begin{array}{l}\text { Skor } \\
\text { Nilai }\end{array}$ & $\begin{array}{c}\text { Kete- } \\
\text { rangan }\end{array}$ \\
\hline 15 & 2 & 1 & 2 & 3 & 2 & 2 & 2 & 14 & \multirow{14}{*}{ 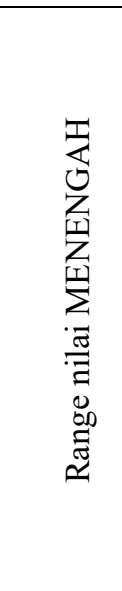 } \\
\hline 15 & 2 & 1 & 2 & 3 & 2 & 2 & 2 & 14 & \\
\hline 14 & 3 & 2 & 2 & 2 & 2 & 2 & 2 & 15 & \\
\hline 14 & 2 & 2 & 2 & 2 & 2 & 2 & 2 & 14 & \\
\hline 14 & 3 & 2 & 2 & 2 & 2 & 2 & 2 & 15 & \\
\hline 14 & 2 & 2 & 2 & 2 & 2 & 2 & 2 & 14 & \\
\hline 13 & 2 & 1 & 2 & 2 & 2 & 2 & 3 & 14 & \\
\hline 13 & 2 & 1 & 2 & 2 & 2 & 2 & 3 & 14 & \\
\hline 12 & 2 & 2 & 1 & 2 & 2 & 2 & 2 & 13 & \\
\hline 12 & 3 & 2 & 2 & 2 & 1 & 2 & 2 & 14 & \\
\hline 12 & 2 & 2 & 2 & 2 & 2 & 2 & 2 & 14 & \\
\hline 12 & 2 & 2 & 1 & 2 & 2 & 2 & 2 & 13 & \\
\hline 12 & 3 & 2 & 2 & 2 & 1 & 2 & 2 & 14 & \\
\hline 12 & 2 & 2 & 2 & 2 & 2 & 2 & 2 & 14 & \\
\hline 11 & 2 & 2 & 2 & 3 & 2 & 3 & 3 & 17 & \multirow{38}{*}{ 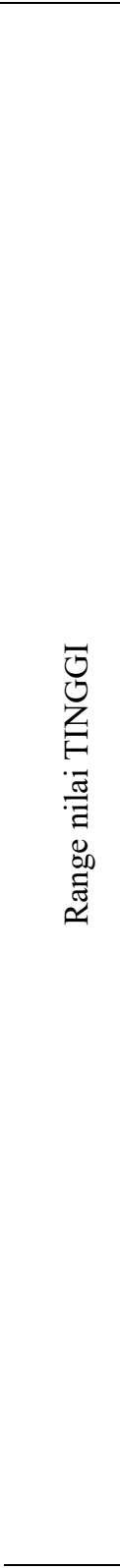 } \\
\hline 11 & 2 & 1 & 2 & 1 & 3 & 2 & 2 & 13 & \\
\hline 11 & 3 & 2 & 2 & 2 & 2 & 2 & 2 & 15 & \\
\hline 11 & 2 & 1 & 2 & 2 & 2 & 2 & 2 & 13 & \\
\hline 11 & 1 & 1 & 2 & 2 & 2 & 2 & 3 & 13 & \\
\hline 11 & 2 & 2 & 2 & 3 & 2 & 3 & 3 & 17 & \\
\hline 11 & 2 & 1 & 2 & 1 & 3 & 2 & 2 & 13 & \\
\hline 11 & 3 & 2 & 2 & 2 & 2 & 2 & 2 & 15 & \\
\hline 11 & 2 & 1 & 2 & 2 & 2 & 2 & 2 & 13 & \\
\hline 11 & 1 & 1 & 2 & 2 & 2 & 2 & 3 & 13 & \\
\hline 10 & 2 & 2 & 3 & 3 & 2 & 2 & 3 & 17 & \\
\hline 10 & 3 & 2 & 2 & 2 & 2 & 2 & 2 & 15 & \\
\hline 10 & 2 & 2 & 3 & 3 & 2 & 2 & 3 & 17 & \\
\hline 10 & 3 & 2 & 2 & 2 & 2 & 2 & 2 & 15 & \\
\hline 9 & 2 & 2 & 2 & 1 & 2 & 2 & 2 & 13 & \\
\hline 9 & 2 & 2 & 2 & 2 & 2 & 2 & 2 & 14 & \\
\hline 9 & 2 & 2 & 2 & 1 & 2 & 2 & 2 & 13 & \\
\hline 9 & 2 & 2 & 2 & 2 & 2 & 2 & 2 & 14 & \\
\hline 8 & 2 & 2 & 2 & 3 & 2 & 2 & 2 & 15 & \\
\hline 8 & 3 & 2 & 2 & 2 & 3 & 2 & 2 & 16 & \\
\hline 8 & 1 & 1 & 2 & 2 & 2 & 1 & 2 & 11 & \\
\hline 8 & 1 & 1 & 2 & 2 & 2 & 2 & 3 & 13 & \\
\hline 8 & 2 & 2 & 3 & 2 & 3 & 3 & 3 & 18 & \\
\hline 8 & 2 & 1 & 2 & 2 & 3 & 3 & 2 & 15 & \\
\hline 8 & 2 & 1 & 2 & 2 & 1 & 2 & 2 & 12 & \\
\hline 8 & 2 & 1 & 2 & 3 & 2 & 2 & 2 & 14 & \\
\hline 8 & 2 & 2 & 2 & 3 & 2 & 2 & 2 & 15 & \\
\hline 8 & 3 & 2 & 2 & 2 & 3 & 2 & 2 & 16 & \\
\hline 8 & 1 & 1 & 2 & 2 & 2 & 1 & 2 & 11 & \\
\hline 8 & 1 & 1 & 2 & 2 & 2 & 2 & 3 & 13 & \\
\hline 8 & 2 & 2 & 3 & 2 & 3 & 3 & 3 & 18 & \\
\hline 8 & 2 & 1 & 2 & 2 & 3 & 3 & 2 & 15 & \\
\hline 8 & 2 & 1 & 2 & 2 & 1 & 2 & 2 & 12 & \\
\hline 8 & 2 & 1 & 2 & 3 & 2 & 2 & 2 & 14 & \\
\hline 7 & 2 & 2 & 2 & 2 & 2 & 2 & 3 & 15 & \\
\hline 7 & 1 & 3 & 1 & 2 & 1 & 1 & 2 & 11 & \\
\hline 7 & 1 & 1 & 2 & 2 & 2 & 2 & 3 & 13 & \\
\hline 7 & 3 & 3 & 2 & 2 & 2 & 2 & 3 & 17 & \\
\hline
\end{tabular}




\begin{tabular}{|c|c|c|c|c|c|c|c|c|c|}
\hline $\begin{array}{c}\text { Durasi } \\
\text { (Jam/ } \\
\text { Minggu) }\end{array}$ & $\begin{array}{l}\text { Nilai } \\
\text { MTK }\end{array}$ & $\begin{array}{l}\text { Nilai } \\
\text { IPA }\end{array}$ & $\begin{array}{l}\text { Nilai } \\
\text { B.Ind }\end{array}$ & $\begin{array}{l}\text { Nilai B. } \\
\text { Ingg }\end{array}$ & Nilai SB & $\begin{array}{c}\text { Nilai } \\
\text { PraKar }\end{array}$ & $\begin{array}{c}\text { Nilai } \\
\text { IPS }\end{array}$ & $\begin{array}{l}\text { Skor } \\
\text { Nilai }\end{array}$ & $\begin{array}{l}\text { Kete- } \\
\text { rangan }\end{array}$ \\
\hline 7 & 2 & 2 & 2 & 2 & 2 & 2 & 3 & 15 & \\
\hline 7 & 1 & 3 & 1 & 2 & 1 & 1 & 2 & 11 & \\
\hline 7 & 1 & 1 & 2 & 2 & 2 & 2 & 3 & 13 & \\
\hline 7 & 3 & 3 & 2 & 2 & 2 & 2 & 3 & 17 & \\
\hline 6 & 2 & 1 & 2 & 2 & 2 & 2 & 2 & 13 & $\Psi$ \\
\hline 6 & 2 & 2 & 2 & 2 & 2 & 2 & 2 & 14 & పే \\
\hline 6 & 2 & 1 & 2 & 2 & 2 & 2 & 2 & 13 & $\tilde{\simeq} \equiv Z$ \\
\hline 6 & 2 & 2 & 2 & 2 & 2 & 2 & 2 & 14 & $\vec{q}$ \\
\hline
\end{tabular}

Sumber: Hasil analisis kuesioner

Dari tabel hasil sortir di atas dapat diketahui bahwa siswa yang menggunakan internet 7 sampai 11 jam memiliki skor nilai yang lebih tinggi dibandingkan yang lainnya. Dengan demikian dapat dikatakan bahwa rentang penggunaan waktu terbaik (ideal) berada pada kisaran 7-11 jam per minggu atau 1-1,5 jam per hari. Sedangkan penggunaan di bawah 7 jam per minggu dan penggunaan di atas 11 jam per minggu tidak memberikan pengaruh yang signifikan terhadap peningkatan prestasi. Bisa dimaklumi jika siswa yang memiliki kekerapan komunikasi dan interaksi akan memiliki keterampilan sosial yang tinggi, akibatnya mereka memiliki potensi untuk untuk berkomunikasi aktif dengan orang lain, termasuk membicarakan materi pelajaran dengan sesama teman atau bahkan dengan guru. ${ }^{21}$ Keterampilan sosial yang tinggi yang dimiliki siswa akan semakin menumbuhkan percaya diri bagi siswa dalam mengikuti pelajaran dan akhirnya potensi siswa dalam meraih prestasi akan lebih baik lagi. Dengan demikian, semakin tinggi kriteria keterampilan sosial dengan penggunaan gadget pada siswa, maka prestasi belajarnya akan semakin meningkat pula.

Meskipun telah menunjukan presntasi yang signifikan dengan tingkat penggunaan smarphone pada siswa, namun sekolah juga harus bijak dalam mengontrol penggunaanya agar tidak kebablasan. Guru harus dapat menciptakan cara dengan tidak menjadikan smartphone sebagai satu-satunya media atau sarana dalam pembelajaran di sekolah. Siswa dapat diarahkan untuk juga mencintai dan akrab dengan buku-buku cetak disamping e-book dengan mengajak dan memotivasi untuk mengunjungi perpustakaan sekolah atau perpustakaan lain.

Sebagai teladan, guru tidak hanya memberikan pelajaran kepada para siswa, tetapi juga mampu menkadi contoh yang baik. Jika guru mengajari siswa untuk bijak menggunakan smartphone secara proporsional, maka guru juga tidak dapat sekehendak hati mengangkat telepon ketika sedang mengajar, tidak bermain game online atau media social selama mengajar. Dengan demikian, maka sekolah menjadi contoh teladan dan pioner dalam pemanfaatan teknologi yang ramah social. Untuk menciptakan sekolah yang responsif teknologi tetapi juga ramah social, maka sekolah harus terus memberikan kegiatan ekstrakurikuler yang mampu menjaring ide siswa yang kreatif dan inovatif lewat penggunaan smartphone dan internet secara umum. Untuk itu, sekolah harus memiliki ide-ide yang dapat merangsang minat dan motivasi siswanya.

\section{Capaian Kognitif (Prestasi Akademik)}

Sebagian besar responden $(72,86 \%)$ memiliki nilai akademis yang baik yakni diatas Kriteria Ketuntasan Minimal (KKM) 22 untuk seluruh mata pelajaran yang ditanyakan dalam

${ }^{21}$ Tania Clara Dewanti, Widada, Triyono,...

${ }^{22}$ KKM (Kriteria Ketuntasan Minimal) adalah kriteria paling rendah untuk menyatakan peserta didik mencapai ketuntasan. Guru atau kelompok guru menetapkan KKM mata pelajaran dengan mempertimbangkan 
kuesioner yakni Matematika, IPA, Bahasa Indonesia, Bahasa Inggris, Seni Budaya, Prakarya, dan IPS. Sementara itu 14,67\% memiliki nilai diatas 90 sedangkan sisanya $12 \%$ responden memiliki nilai dibawah 75 .

Mata pelajaran sosial, keterampilan dan komunikasi memiliki nilai yang lebih besar dibandingkan dengan pelajaran eksakta (Matematika dan IPA). Hal ini menjelaskan bahwa siswa yang menggunakan internet memiliki wawasan yang lebih luas, memiliki keterampilan berbahasa asing, dan mampu mengembangkan kreatifitasnya. Lebih jelasnya Capaian prestasi akademik disajikan dalam tabel di bawah ini.

Tabel 4; Capaian Kognitif (Prestasi Akademik)

\begin{tabular}{cccccccccccc}
\hline \multirow{2}{*}{ No. $\begin{array}{c}\text { Kelompok } \\
\text { Nilai }\end{array}$} & MTK & IPA & $\begin{array}{c}\text { B. } \\
\text { Indo }\end{array}$ & B. Ingg & SB & $\begin{array}{c}\text { Pra } \\
\text { Karya }\end{array}$ & IPS & Jumlah & $\%$ \\
\hline 1 & $<75$ & 10 & 24 & 4 & 4 & 6 & 4 & - & 52 & 12 \\
\hline 2 & $75-90$ & 38 & 32 & 52 & 46 & 46 & 50 & 42 & 306 & 72.86 \\
3 & $>90$ & 12 & 4 & 4 & 10 & 8 & 6 & 18 & 62 & 14.76 \\
\hline & Total & 60 & 60 & 60 & 60 & 60 & 60 & 60 & 420 & 100.00 \\
\hline \multicolumn{2}{c}{ Persentase } & 14.29 & 14.29 & 14.29 & 14.29 & 14.29 & 14.29 & 14.29 & 100.00 & \\
\hline
\end{tabular}

Sumber: Hasil analisis kuesioner

2. Analisis Pengaruh

Untuk melihat pengaruh penggunaan internet terhadap prestasi siswa menggunakan analisis statistik. Analisis dilakukan dengan bantuan perangkat lunak MS-Excell. ${ }^{23}$ Hasilnya ditunjukan oleh tabel sebagai berikut:

Tabel 5; Hasil Analisis Regresi Antara Variabel Durasi Penggunaan Internet Dengan Prestasi Akademik

\begin{tabular}{l|r}
\hline \multicolumn{2}{c}{ Regression Statistics } \\
Multiple R & 0.378515 \\
R Square & 0.143273 \\
Adjusted R Square & 0.027945 \\
Standard Error & 2.441933 \\
Observations & 60 \\
\hline
\end{tabular}

Sumber: Hasil analisis regresi menggunakan MS-Excell.

Dari tabel di atas dapat ditafsirkan secara sederhana bahwa ada hubungan yang sangat erat yaitu 0,378515 antara durasi penggunaan internet dengan capaian prestasi. Tanda Positif menunjukkan bahwa hubungannya searah. Jika Persentase durasi penggunaan internet tinggi maka maka Tingkat prestasi juga semakin tinggi. Apabila dikuardratkan R2 tingkat determinasi/sumbangan efektif sebesar $0,143273(14,32 \%)$ artinya variabel lamanya penggunaan internet memiliki sumbangan efektif 14,32\% (dampak/implikasi) sisanya 6,33\% dipengaruhi oleh lain-lain. Besar kontribusi penggunaan internet terhadap tingkat prestasi adalah 0,0279 atau $2,79 \%$.

tiga aspek kriteria, yaitu kompleksitas, daya dukung, dan intake peserta didik. https://inasari894.wordpress.com/2013/12/24/205/

23 Tata cara perhitungan mengacu https:/junaidichaniago.wordpress.com/2008/06/25/analisis-regresidengan-excel/ (diakses 10 Januari 2018) 
Penggunaan internet tidak dapat dipungkiri memiliki manfaat positif dalam menawarkan mteode dan media pembelajaran. Hal inilah yang digunakan oleh para guru dalam mengajarkan materi pembelajaran kepada para siswa, dalam banyak penelitian membuktikan bahwa cara ini mampu meningkatkan prestasi siswa ${ }^{24}$. Ada perbedaan motivasi belajar antara siswa yang diajarkan pembelajaran dengan menggunakan media internet dibandingkan siswa yang diajarkan pembelajaran konvensional. Media ini mempengaruhi prestasi dan hasil belajar dengan menggunakan media tersebut. Dengan demikian, maka penggunaan internet terutama smartphone memiliki dampak positif hasil belajar siswa.

Bagaimanapun penggunaan internat bagi masyarakat merupakan sesuatu yang perlu dan tidak bisa dihindari dewasa ini. Internet sudah melanda hampir semua level masyarakat, bahkan juga telah merambah pada dunia pendidikan. Jika banyak riset menunjukan bahwa internet memiliki dampak negatif. Namun sebagaimana hanya produk teknologi lainya, internet atau khususnya smartphone juga memiliki dua sisi mata uang, ia bisa berdampkak positif dan juga negatif tergatung siapa yang menggunakan dan untuk apa. Penggunaan smartphone pada dunia pendidikan saat ini juga menjadi hal yang "wajib", sebab era digital dan dunia global menunut dunia pendidikan untuk tidak abai terhadap fenomena ini. Trend penggunaan smartphone dikalangan siswa menjadi meningkat secara terus menerus. Hal ini sejalan dengan konsep keterampilan dan kecerdasan sosial seorang anak ditentukan dengan keterampilanya dalam berinteraksi dan berkomunikasi dengan orang lain. ${ }^{25}$ Smartphone dalam hal ini adalah media menjembatani komunikasi tersebut. Maka tidak heran jika penggunaan smartphone dalam mengakses pembelajaran dan bahan mata penajaran berjalan seiring dengan peningkatan prestasi belajar siswa. Trend penggunaan smartphone ini merupakan penanda era masyarakat digital. ${ }^{26}$ Artinya bahwa setiap aktivitas manusia akan digerakkan melalui serangkaian teknologi digital yang dioperasikan dengan beberapa digit (angka). Relasi yang dibangun adalah relasi pertukaran digital, lewat simbol-simbol digital. Jika hal ini dibiarkan terus dan tak diibangi dengan interaksi sosial secara nyata dan faktual, maka hubungan antar manusia nantinya adalah hubungan digital secara simbolis semata, dengan mengenyampingkan relasi kemanusiaan yang juga sarat nilai-nilai kemanusiaan. Jika demikian, maka prestasi siswa apakah juga cukup hanya diukur dengan angka-angka kuantitatif. Sementara keberhasilan siswa tidak hanya kepintaran kognitif, tetapi juga kecerdasan sosial dan emosional sekaligus. Untuk itu penelitian-penelitian lebih lanjut terkait penggunaan smartphone dalam banyak aspek yang terkait erat dengan capaian prestasi belajar siswa perlu terus dilakukan, diperbaharui, dan dikontekstualisasikan.

\section{Penutup}

Penggunaan internet ataupun smartphone sudah mulai berkembang di kalangan pelajar, khususnya pelajar di MTs Negeri 7 Model Jakarta. Sebagian besar remaja mengakses internet melalui perangkat cerdas (smartphone), hanya sedikit menggunakan jasa Warnet. Akses terhadap internet bagi seluruh responden hanya dilakukan di luar lingkungan sekolah. Hal ini berdasarkan kebijakan dan aturan sekolah yang melarang penggunaan internet saat siswa bersekolah. Akses internet yang dilakukan di luar sekolah atau rumah masing-masing siswa menggunakan akses data dari provider kartu berbayar pada smartphone dan sambungan WIFI. Konsumsi data yang dihabiskan oleh masing-masing responden sebagian besar di atas 1

\footnotetext{
${ }^{24}$ Lihat penelitian Sulihin B. Sjukur, "Pengaruh Blended Learning Terhadap Motivasi Belajar Dan Hasil Belajar Siswa Tingkat SMK", Jurnal Pendidikan Vokasi, Vol 2, Nomor 3, November 2012: 368-378; Lihat pula hasil penelitian Beauty Manumpil, Yudi Ismanto, \& Franly Onibala tentang "Hubungan Penggunaan Gadget Dengan Tingkat Prestasi Siswa Di Sma Negeri 9 Manado",...

${ }^{25}$ Tania Clara Dewanti, Widada, Triyono,...

${ }^{26}$ Muhamad Ngafifi, "Kemajuan Teknologi Dan Pola Hidup Manusia Dalam Perspektif Sosial Budaya", Jurnal Pembangunan Pendidikan: Fondasi dan Aplikasi, Vol. 2, No.1, 2014: 33-47.
} 
Gigabyte (GB) per bulan, meskipun ada yang pengunaannya lebih rendah, yakni berkisar antara 500 Megabyte (MB) hingga 1GB per bulan. Sementara belanja pulsa untuk aktivasi paket data berkisar antara $25.000-50.000$ Rupiah per bulan. Sumber pembelian pulsa dan data cukup beragam, sebagian besar sudah mampu menyisihkan uang jajan untuk pembelian pulsa, namun sebagian mengaku masih membebankan biaya pembelian pulsa kepada orang tua, dan sumber lainnya.

Pengaruh penggunaan internet terhadap prestasi bahwa internet ataupun smartphone tidak selalu berdampak negatif terhadap capaian prestasi di MTsN 7 Model Jakarta. Hasil penelitian menunjukan bahwa ada hubungan yang sangat erat antara durasi penggunaan internet dengan capaian prestasi. Tanda positif dalam hubungan regresi menunjukkan bahwa hubungannya searah, yakni jika durasi penggunaan internet tinggi maka maka tingkat prestasi juga semakin tinggi. Capaian prestasi Mata pelajaran sosial, keterampilan dan komunikasi memiliki nilai yang lebih besar dibandingkan dengan pelajaran eksakta (Matematika dan IPA). Hal ini menjelaskan bahwa siswa yang menggunakan internet memiliki wawasan yang lebih luas, memiliki keterampilan berbahasa asing, dan mampu mengembangkan kreatifitasnya. Rentang penggunaan waktu terbaik (ideal) berada pada kisaran 7-11 jam per minggu atau 1-1,5 jam per hari. Sedangkan penggunaan di bawah 7 jam per minggu dan penggunaan di atas 11 jam per minggu tidak memberikan pengaruh yang signifikan terhadap peningkatan prestasi. Dampak positif penggunaan internet mungkin terjadi apabila penggunaannya diarahkan pada hal-hal yang positif dan penggunaannya dibatasi di luar jam sekolah.

Selain itu penggunaan teknologi smartphone secara terus menerus akan mengantarkan masyarakat termasuk siswa pada keberpihakan pada komunikasi serta interaksi digital. Jika yang ditonjolkan hanyalah presntasi akademik kognitif lewat capaian angka-angka, maka dikhawatirkan bahwa siswa akan diarahkan pada proses dehumanisasi. Pada titik ini, siswa akan takluk pada teknik dan pada mesin. Pekerjaan rumah yang perlu dipikirkan adalah bagaimana penggunaan internet dalam hal ini smartphone diarahkan pada sisi-sisi kemanusiaan dengan meningkatkan keterampilan komunikasi siswa secara sosial dan emosional. Level ini barangkali yang cukup sulit, tetapi bukan hal yang mustahil jika internet mampu menyentuh sisi kecerdasan sosial dan kecerdasan emosional siswa dengan berbagai aplikasi canggih yang ditawarkanya.

\section{Daftar Pustaka}

Afgani, Muhammad Win, Darmawijoyo, dan Purwoko, "Pengembangan Media Website Pembelajaran Materi Program Linear Untuk Siswa Sekolah Menengah Atas", Jurnal Pendidikan Matematika, Vol. 2. No.2, (Juli-Des 2008): 45-59.

Al-Ayouby, M. Hafiz. "Dampak Penggunaan Gadget Pada Anak Usia Dini (Studi di PAUD dan TK.Handayani Bandar Lampung)”. Skripsi Universitas Lampung 2017

Daeng, Intan Trivena Maria, N.N Mewengkang, Edmon R Kalesaran. "Penggunaan Smartphone Dalam Menunjang Aktivitas Perkuliahan Oleh Mahasiswa Fispol Unsrat Manado", e-journal Acta Diurna, Vol. VI. No. 1. Tahun 2017: 1-15.

Dewanti, Tania Clara Widada \& Triyono, "Hubungan Keterampilan Sosial Dan Penggunaan Gadget Smartphone Dengan Prestasi Belajar Siswa Sma Negeri 9 Malang", Jurnal Kajian Bimbingan dan Konseling Vol 1, No. 3, 2016: 126-131

Dewi Irmawati, "Pemanfaatan E-Commerce Dalam Dunia Bisnis", Jurnal Ilmiah Orasi Bisnis, Edisi Ke-VI, (November 2011): 95-112. 
Manumpil, Beauty Yudi Ismanto, Franly Onibala. "Hubungan Penggunaan Gadget Dengan Tingkat Prestasi Siswa Di SMA Negeri 9 Manado", ejoural Keperawatan (e-Kep), Vol. 3. No. 2 (April 2015).

Munadi, Yudhi. Media Pembelajaran: Sebuah Pendekatan Baru. Jakarta, 2013

Ngafifi, Muhamad "Kemajuan Teknologi Dan Pola Hidup Manusia Dalam Perspektif Sosial Budaya", Jurnal Pembangunan Pendidikan: Fondasi dan Aplikasi, Vol. 2, No.1, 2014: $33-47$.

Rahardiyan, Elfan K., "Pemanfaatan Internet Dan Dampaknya Pada Pelajar Sekolah Menengah Atas Di Surabaya", dalam http://journal.unair.ac.id/filerPDF/ln5ba2011865full.pdf (diakses 15 Pebruari 2018)

Sherlyanita, Astrid Kurnia \& Nur Aini Rakhmawati, "Pengaruh dan Pola Aktivitas Penggunaan Internet serta Media Sosial pada Siswa SMPN 52 Surabaya", Journal of Information Systems Engineering and Business Intelligence, Vol. 2, No. 1 (April 2016): 17-22.

Susena, Edy. "Dampak Penggunaan Internet Terhadap Kecerdasan Pelajar", 2016, dalam http://www.poltekindonusa.ac.id/wp-content/uploads/2016/05/Vol-1-2-2014-

DAMPAK-PENGGUNAAN-INTERNET-TERHADAP-KECERDASANPELAJAR-Edy-Susena.pdf

Sjukur, Sulihin B. "Pengaruh Blended Learning Terhadap Motivasi Belajar Dan Hasil Belajar Siswa Tingkat SMK", Jurnal Pendidikan Vokasi, Vol 2, Nomor 3, November 2012: 368-378.

\section{Website;}

"14 Dampak Buruk Smartphone Bagi Anak Tercinta - Jurnal Web” diakses 11 Januari 2018, https://www.jurnalweb.com/dampak-buruk-smartphone-bagi-anak/

"33\% Pengguna Akses Ponsel Pintar lebih dari 8 Jam/Hari - Databoks," diakses 11 Januari 2018, https://databoks.katadata.co.id/datapublish/2016/11/02/33-pengguna-smartphone Blais, "Adolescents Online: The Importance of Internet Activity Choice to Salient Relationships". Journal Youth Adolescence, 37:522-

536. (Online). (http://repository.unand.ac.id), Diakses 12 April 2017.

Isna, Nadhila. "Mempermudah Hidup Manusia dengan Teknologi Modern".

(Online).(http://komunikasi.us/index.php/mata-kuliah/kmm/12-response-paper-ptk2013/375mempermudah-hidup-manusia-dengan-teknologi-modern), Diakses 12 April 2017.

https://junaidichaniago.wordpress.com/2008/06/25/analisis-regresi-dengan-excel/ (diakses 10 Januari 2018)

Katadata.co.id, "Pengguna Smartphone Tertinggi di Asia-Pasifik 2016- Databoks", https://databoks.katadata.co.id/datapublish/2016/08/08/pengguna-smartphonetertinggi-di-asia-pasifik-2016, diakses 11 Januari 2018

Katadata.co.id, "33\% Pengguna Akses Ponsel Pintar lebih dari 8 Jam/Hari - Databoks,", https://databoks.katadata.co.id/datapublish/2016/11/02/33-pengguna-smartphoneakses-perangkatnya-lebih-dari-8-jam-per-hari, diakses 11 Januari 2018 
Liputan6. "Anak Asuhan Gadget”, https://www.liputan6.com/health/read/2460330/anakasuhan-gadget, diakses 12 Oktober 2018.

Liputan6. $\quad$ https://www.liputan6.com/tekno/read/3593233/wajib-tahu-ini-dampak-buruksmartphone-ke-tubuh-dan-otak, diakses 3 Maret 2018

Novalius, Feby. "Indonesia Pengguna Smartphone Ke-4 Dunia, Begini Tekad Menperin Dongkrak Industri Telematika", https://economy.okezone.com/read/2018/02/17/320/1860752/indonesia-penggunasmartphone-ke-4-dunia-begini-tekad-menperin-dongkrak-industri-telematika, diakses 2 Oktober 2018.

"Pengguna Smartphone Tertinggi di Asia-Pasifik 2016- Databoks", diakses 11 Januari 2018. https://databoks.katadata.co.id/datapublish/2016/08/08/pengguna-smartphonetertinggi-di-asia-pasifik-201

PewResearchCenter, "Internet User by Age Groups". http://www.pewinternet.org/, diakses 2 Januari 2017.

Saragih, H P, "Belajar Tak Lagi Membosankan". www.wartaekonomi.com. (http://detiknas.in/donesia/2007/09/19/belajartak-lagi-membosankan/, diakses tanggal 27 Oktober 2017. 